\title{
Financial Development and Economic Growth in Developed Countries
}

\author{
Mohsen Mehraraa ${ }^{a}$, Fateme Ghamati ${ }^{b}$ \\ Faculty of Economics, University of Tehran, Kargar-e-shomali, Po Box 14166-6445, Tehran, Iran \\ ${ }^{a, b}$ E-mail address: mmehrara@ut.ac.ir ,ghamati2422@gmail.com
}

\begin{abstract}
Financial development is one of the keys to the long-run economic growth. Since economic growth is one of the important goals of every country, the investigation of the causes of economic growth is vital so that planners and policy makers should pay attention to it. Economists traditionally focusing on the long-run relationship between financial development and economic growth have argued that the development of financial section by efficient resource allocation and financing innovative activities can support and boost economic growth. The relationship between financial development and economic growth is one of the macroeconomic relations which were investigated in empirical studies in Iran and other countries. Some economists believe that financial section has no effect on real section but the literature shows a strong relationship between financial development and economic growth. In this research the effect of indicators of financial development on economic growth of developed countries is investigated by using panel data in 10 chosen countries during 1997-2007. The results show that financial development indicator has an important effect on level of GDP, also other explanatory variables are statistically significant in economic growth. Therefore it can be said that supply of financial markets would boost economic growth.
\end{abstract}

Keywords: Financial Development; Economic Growth; Panel Data

Classification JEL: E44, O16, O47

\section{INTRODUCTION}

A prerequisite for economic growth in every country is financial development. Studies show that financial resources are not allocated to the needs efficiently in countries with weak financial section. Countries sometimes encounter the lack of financing tools and therefore enough resources are not obtained. Developing financial section of a country is a factor for attaining remarkable and continuous economic growth. Countries with more developed financial system would quickly be in the path of economic growth because of providing the ability to experience economic growth for other countries. Market based system at the macro level, is based on commodity, labor market, money market and capital market. Today financial section of countries is often divided into money market and capital market. Political and economic stability is one of the important goals of every country that can be achieved by developing financial market that is a pillar of modern societies. Many economists believe that the importance of financial section is due to the fact that the efficient financial section has an 
important role in mobilization of financial resources for investment, encouraging entry and mobilization of foreign capital and the optimization of allocation mechanism.

Financial development is in fact the development of financial system including markets, institutions and financing tools, so one can consider financial section as the second half of economics that completes its real part. Achieving economic growth requires creation of some social, cultural and economic mechanism. Robust financial markets are considered such mechanisms in the economic sphere. Having robust financial markets demand for powerful financial institutions. Functions of financial system including finding information about investment opportunities, aggregating savings, monitoring investment and facilitating the exchange of goods and services will reduce transaction costs and optimize resource allocation and finally lead to economic growth. Optimal function of economic system in any country requires that its real section and financial section be efficient, robust and monitored. It is necessary and sufficient for any economic system that these two sectors work together. Failure in one section would affect the other one negatively. Therefore stable and long-run balance of economic system is achieved whenever these two sectors work together in an efficient and balanced way. The first part of this article is devoted to the literature and studies which have been done in this field. In the second section theories about the relationship between financial development and economic growth are discussed. The research method, model estimation and analysis and the results are given in final section.

\section{EMPRICAL LITERATURE}

Goldsmith (1969) and McKinnon (1973) provided some analytic foundations for this view and supported it with simple but persuasive observations. These treatments stress the role of repression as manifested in government interventions on the financial sector, such as ceilings on interest rates and directed credit programs, in hampering financial development and thereby reducing rates of factor accumulation and productivity growth.

King and Levine (1993) ran cross-country growth regressions that covered 80 countries and found that those with greater initial levels of financial activity grew faster over the 19601990 period than those with less financial development. They also found that financial development promoted productivity growth by inducing technological innovation.

Rousseau and Wachtel (1998) applied the VAR approach to five industrialized countries over the 1870-1929 period and found strong uni-directional links from finance to growth. They also estimated a vector error correction model (VECM) for each country and found evidence of an economically important long-run relationship between the two sectors.

This paper takes a time series approach to investigate whether the intensity of financial intermediation promoted investment and growth in 10 Asian economies over the 1950-2000 period. Rousseau and Vuthipadadorn (2005) do this by using vector autoregressive models (VARs) and vector error correctionmodels (VECMs) to examine the natureof statistical causality between measures of financial and real sector activity. results indicate that finance did, on the whole, act as a driving force behind investment. Evidence of a role for financial factors in output is weaker. The findings are consistent with a factor accumulation channel as the primary mechanism through which the financial sector influenced macroeconomic outcomes in these countries.

In Iran Komeyjani and Pourrostami studied the effect of financial repression on the economic growth. They investigated various forms of economic oppression according to the real interest rate and by using integrated data they investigated its effect on the economic 
growth in 90 countries during the years 1985-2005. The results showed a significant negative impact of the negative real interest rate on the economic growth of countries. In fact the more negative real interest rate the more negative impact on economic growth.

Motmani studied the relationship between financial development and the economic growth in Iran during 1340-1385. The results showed that in economic system of Iran, economic growth lead to financial development but reverse causality is not corroborated by statistical evidence.

Rasekhi and ranjbar have investigated the impact of financial development on the economic growth of OIC member states during 1980-2004. This study showed the positive effect of financial development on economic growth of these countries. Financial development by private factor is more influential than development of banking sector in economy.

\section{THEORIES}

That the relationship between financial development and the economic growth has been considered by many economists. Unlike Ricardo who had concentrated on shortage of production factors such as land and capital as limiting factors of economic growth and ignored financial markets, Schumpeter states that the importance of intermediary services is in modernization and development of economy. About the nature of relationship between financial sector and real sector, he says that: for every real flow of goods and services there exists a financial flow which moves exactly in opposite direction. It shows that these two sectors are interconnected. Theoretical relationship between financial development and economic growth is related to Schumpeter's studies (1934). In his opinion, financial intermediation services are vital for economic development. He states that the financial intermediaries through banking system and affecting savings allocation, increasing productivity and technological change of economic growth destroy the mediating role adopted by financial institutions and the information asymmetry between savers and borrowers. In this way they perform the functions of saving mobilization, capital allocation, monitoring inventory usage and risk management. All of these processes affect economic growth.

Some theorists believe that financial system does not influence economic growth, for example Robinson (1952) said that financial development does not motivate economic growth and only shows the development rate of real sector.

McKinnon and Shaw (1973) have discussed the importance of an efficient financial system in economic development. They expressed the limitations which can affect the economic development by an inefficient financial sector. In their opinion, government restriction on financial sector (such as interest rate control, central bank reverse rate and credit allocation) can bring about some problems in the process of financial sector development that in turn lead to restriction in real sector development.

Theories about the impact of financial development on the economic growth can be divided into three perspectives. The first is the perspective of advocates of the supply. They assume that efficient financial market will increase service supply and demands for the real part of economic system. This theory became widespread by economists like Shaw, McKinnon and Fry (1978). Some economists like Robinson and Patrick object this theory. They believe that it is the real section of economic system which helps development of financial section. According to this view, change in financial market is reactive to economic growth. Therefore the growth of real part is due to the technology development. Other economists believe that financial development is not quite related to economic growth. For example, in his studies, 
Stern 1989 has ignored the role of financial development in the economic growth. Like Stern, Lukas (1988) says that some economists have insisted on the role of financial markets in the economic growth too much. He believes that in optimal condition, the role of these markets should not be exaggerated. Lukas has changed the traditional patterns of growth by extending endogenous growth theory. The equation $\mathrm{Y}=\mathrm{AK}$ is the essence of endogenous growth theory. $\mathrm{A}$ is science and technology factor and $\mathrm{K}$ is human and physical capital. He did not clearly put in to the model the development of financial section. He even calls the relationship with other economists assume between financial development and economic growth, hyperbolic.

To sum up, the studies done by goldsmith 1369, Show and McKinnon show a positive correlation between financial development and economic growth. Robinson and Patrick 1966 believe that the economic growth increase financial markets. In the 1980s, some economists said that financial development doesn't have that much impact on the economic growth. (Lukas 1988), and even some of them ignored such impacts (Sternson 1989).

\section{METHODOLOGY AND DATA}

This study investigates the impact of financial development on the level of GDP growth by using Panel data in ten developing countries such as: Canada, England, japan, Spain, Germany, America, Netherlands, Switzerland, Italy, and Russia during 1999-2007. The data were collected by world development indicators (WDI).

\section{1. The model}

In this research we assume that the economic growth is directly dependent on financial development and the other explanatory variables like export, human capital, the value-added agriculture. According to king and Levines' model, the following is the formula of this relation:

$$
g=\alpha_{0}+\alpha_{1} F D+\alpha_{i} W_{i} \quad \mathrm{i}=1,2,3, \ldots
$$

In this model, $g$ is the growth rate of per capita income, $F D$ is financial development indicator and $W_{i}$ indicates the other explanatory variables that affect per capita income both qualitative and quantitative. By adding a random error to the above formula/equitation a general econometric model can be obtained which can be used for measuring the size of various growth determining factors. To study and evaluate the relationship between financial development and economic growth in the chosen countries, we use panel data. After adding control variables to the above/ (1) equitation, the model will be as the formula bellow:

$$
L G D P_{i t}=C+\beta_{1} L F D_{i t}+\beta_{2} L H C_{i t}+\beta_{3} L X_{i t}+\beta_{4} L A V A_{i t}+U_{i t}
$$

In this equation, FD is the ratio of domestic credit to the private sector to GPD; HC is human capital indicator that is equal to average years of education of people above 25 -years old and is introduced by Barro and Lee 2012, X is the ratio of exports to GDP, AVA is agricultural value added to GDP, $\mathrm{L}$ indicates common/natural logarithm and $\mathrm{t}$ and $\mathrm{I}$ are indicators of year and country respectively. To estimate the model, first pool test should be done against panel test and this is recognized by the following F statistics: 


$$
F=\frac{\left(\mathbf{e}_{r}^{\prime} \mathbf{e}_{r}-\mathbf{e}_{u}^{\prime} \mathbf{e}_{u}\right) /(N-1)}{\mathbf{e}_{w}^{\prime} \mathbf{e}_{w} /(N T-K-N)} \sim F_{(N-1),(N T-K-N)}
$$

In the above formula, $\mathrm{N}$ is the number of countries, $\mathrm{K}$ is non-intercept parameter and $\mathrm{T}$ indicates time. In this test, null hypothesis is the sum of square roots of the waste least squares for bound pool model. The opposite hypothesis is the sum of square roots of the waste least squares for unbound fixed effects. If the null hypothesis is rejected, the model is panel. In the next step the type of data in terms of random effects and fixed effects should be tested and for recognition, Hasman test is used. If the null hypothesis is rejected, the data type is Panel with fixed effects.

In developed countries, the amount of computational $\mathrm{F}$ is 893.46 and the amount of $\mathrm{F}$ in table is 1.26 which is less than the computational amount. Therefore null hypothesis is rejected and the model is panel. Then using Hasman test we try to recognize whether the panel model has fixed effects or random effects. In this test, the null hypothesis is based on the panel model with random effects. This hypothesis is rejected in this test and the model is recognized with fixed effects.

Table 1 shows the results. Moreover, the empirical results by different countries are given in appendix 1. In investigating the impact of financial development on economic growth, we found these results: financial development indicator has the most impact on economic growth of countries like England, America, Netherlands, Spain and Italy and the relationship between financial development and economic growth is positive and significant in these countries.

Table 1. The effect of financial development on the economic growth in developed countries.

\begin{tabular}{|c|c|c|c|}
\hline \multicolumn{4}{|c|}{ The dependent variable: logarithm of GDP per capita } \\
\hline Variable & Coefficients & T-statistics & prob \\
\hline $\begin{array}{c}\text { Financial Development } \\
\text { Index }\end{array}$ & 0.2 & 10.33 & 0.00 \\
\hline Human Capital Index & 0.44 & 8.38 & 0.00 \\
\hline LX & 0.09 & 4.45 & 0.06 \\
\hline LAVA & -0.19 & -12.98 & 0.00 \\
\hline F-Statistic & & 2073.28 & \\
\hline Prob F & \multicolumn{3}{|}{} \\
\hline
\end{tabular}

Source: research findings

The impact of this indicator was less in other countries especially in Canada. In Germany the relationship between these two variables was negative and meaningful but in countries like Russia, Switzerland and japan it was insignificant, so that in these countries, there is no relationship between these two variables.

The results of the first model show that the all variables used in the model are significant and the signs are compatible with economic theories. According to F test, since P-value is near zero, null hypothesis is rejected and all coefficients are jointly significant. Thus it is confirmed that the model is meaningful. Since the model is specified logarithmically, variable coefficient 
indicates the elasticity of variable respect to the economic growth. Therefore according to the coefficient of financial development indicator, if in these countries financial development increase $10 \%$, the economic growth will rise $2 \%$.

As for the human capital variable, if it increases $10 \%$, the economic growth will rise 4.4 $\%$. This variable is statistically significant has a positive relationship with economic growth.

Export variable shows a positive and meaningful relationship at the level of $10 \%$. If export increases only $1 \%$, these countries will experience $9 \%$ economic growth. But the variable of value added agriculture shows an inverse relationship with economic growth in this model.

\section{CONCLUSION}

For continuous economic growth, an important problem that developed countries are encountered to is how to use financial resources obtained from various economic activities optimally. The relationship between financial development and economic growth can help policy makers of these countries for policy making priority. The relationship between financial development and economic growth has been considered so important in recent years and many economists have investigated it. Empirical results confirm the impact of financial development on economic growth. As was mentioned, this impact is different considering financial markets and economic conditions of countries. So it can be said that: despite the limited growth of financial sector in terms of scale and economic activities during the recent three decades, it has become more important in the economic system.

\section{Acknowledgements}

The authors would like to acknowledge the financial support of university of Tehran for this research under the grant number 4401012/1/28.

\section{References}

[1] Fry M. J., Journal of Money, Credit and Banking 34(4) (1978) 56-65.

[2] Goldsmith R. (1969). Financial Structure and development, New Haven, Yale University Press.

[3] King R. G., R. Levine, Quarterly Journal of Economics 89(3) (1993) 67-55.

[4] Komeyjani A., N. Pourrostami, Economic Research Journal XII (1387) 31-51.

[5] Kul B. L., M. Khan, Journal of Development Economics 94(4) (1999) 9-22.

[6] Mckinnon, R. (1973), Money and Capital in Economic Development, Washington, D.C.: brooking Institution.

[7] Lucas R E., Journal of Monetary Economics 40(2) (1988) 90-103.

[8] Motmani M. (1388). the Investigating of the Relationship Between Financial Development And Economic Growth In Iran, Business Studies, No. 24, April, and May 88 . 
[9] Patrick H. T., Economic Development and Cultural Change 57(3) (1966) 76-89.

[10] Rasekhi S., Ranjbar O., Journal of Development 78(27) (1388) 11-22.

[11] Robinson Joan (1952). The Rate of Interest and Other Essays. London: Macmillan.

[12] Rousseau P. L., Journal of Macroeconomics 88(1) (2005) 55-68.

[13] Rousseau P., Wachtel P., Journal of Money, Credit and Banking 30(4) (19998) 78-89.

[14] Schumpeter Joseph. A. (1934). The Theory of Economic Development, Cambridge: Harvard University Press.

[15] Shaw E. (1973). Financial Deepening in Economic Development, Oxford University press.

[16] Stern N. (1989). The Economics of Development: A Survey, Economic Journal, September.

[17] Lucas R. E. Jr., Econometica 61(2) (1993) 251.

[18] Mohsen Mehrara, Masoumeh zirak, International Letters of Social and Humanistic Sciences 2 (2013) 32-38.

[19] Mohsen Mehrara, Maysam Musai, International Letters of Social and Humanistic Sciences 5 (2013) 55-62.

[20] Mohsen Mehrara, Maysam Musai, International Letters of Social and Humanistic Sciences 8 (2013) 1-7.

[21] Mohsen Mehrara, International Letters of Social and Humanistic Sciences 9 (2013) 59-64.

[22] Mohsen Mehrara, Hamid Abrishami, Mostafa Boroujli, Mahan Amin, International Letters of Social and Humanistic Sciences 11 (2013) 76-83.

[23] Mohsen Mehrara, Amin Haghnejad, Jalal Dehnavi, Fereshteh Jandaghi Meybodi, International Letters of Social and Humanistic Sciences 3 (2014) 1-19. 